ROCZNIKI PEDAGOGICZNE

Tom 11(47), numer specjalny -2019

DOI: http://dx.doi.org/10.18290/rped.2019.11s-24

SYLWIA SKIBICKA

\title{
NARKOMANIA JAKO CZYNNIK KRYMINOGENNY
}

\section{PROBLEM NARKOMANII W POLSCE}

Ludzkość ma dostęp do substancji zmieniających świadomość od wieków. Można uznać, że historia ich używania jest tak długa jak cywilizacja ludzka. W naszej tradycji ludowej znane było świadome wykorzystywanie do celów leczniczych takich roślin, jak lulek czarny, pokrzyk wilcza jagoda czy blekot. Przed II wojną światową zjawisko narkomanii nie stanowiło problemu. Pierwsza dokumentacja leczenia narkomanii w Polsce pochodzi z 1921 roku ze Szpitala Psychiatrycznego w Tworkach. Liczba hospitalizowanych wynosiła 85, a po pięciu latach wzrosła do 295. W tamtym okresie atrakcyjne były takie środki, jak morfina, kokaina i heroina.

Narkomania w Polsce w latach międzywojennych w większości przypadków wynikała z gwałtownie zmieniających się reguł życia, destabilizacji materialnej (inflacja i bezrobocie), zamętu ideologicznego, przemieszczania i reemigracji ludzkości wewnątrz scalonego po zaborach państwa, zmiany obyczajów, w tym „socjopatyzacji” występującej w niektórych środowiskach artystyczno-literackich (Jabłoński, Bukowska, Czabała, 2012).

Nadzór nad dystrybucją środków odurzających w 1919 roku powierzono Departamentowi Służby Zdrowia MSW, a następnie utworzono Instytut Spraw Społecznych, który miał na celu stworzenie krajowego programu zwalczania narkomanii oraz planu systemu lecznictwa. Najważniejszym organem zajmującym się tym problemem stał się Polski Komitet ds. Narkotyków i Zapobiegania Narkomanii. Po II wojnie światowej zjawisko to zaczęło znacznie wzrastać. Oficjalnie rozpoznano problem z końcem lat 60 ., kiedy to rozpowszechnił się on

Sylwia SKIBICKA - studentka pedagogiki specjalnej, Katolicki Uniwersytet Lubelski Jana Pawła II, Instytut Pedagogiki, Wydział Nauk Społecznych; e-mail: sylwiaskibicka@gmail.com 
wśród ludzi młodych. Narkomanią zainteresowały się wtedy kolejne grupy, m.in. pracownicy oświaty (psycholodzy, pedagodzy), kryminolodzy oraz prawnicy. W tamtym czasie stosowane substancje psychoaktywne były kradzione z placówek służby zdrowia, fabryk i aptek oraz uzyskiwane za pomocą zafałszowanych recept. Najczęściej stosowane w tamtych czasach były leki z grupy opiatów, krople Inoziemcowa, psychosymulanty i niektóre leki nasenne, uspokajające. Kolejną atrakcyjną grupą łatwo dostępnych substancji były środki chemiczne (gazy, proszki, benzyna). Początkowo problem bagatelizowano, zepchnięto na margines zainteresowania oraz nałożono zakaz informacyjny (zapis cenzury). Od połowy lat 70. wzrosła tendencja spożywania wyrobów makowych, które nazywano „polską heroiną” lub „kompotem”. Wkrótce opiaty domowej produkcji stały się powszechnym środkiem odurzającym, co skutkowało nagłym wzrostem osób uzależnionych od opiatów. Pomimo tego, społeczeństwo nie podejmowało żadnych działań zmierzających do stworzenia instytucji, która przeciwdziałałaby zjawisku narkomanii.

W 1981 roku zarejestrowano pierwszą w Polsce powojenną organizację pozarządową zajmującą się przeciwdziałaniem narkomanii - Młodzieżowe Stowarzyszenie MONAR (Jabłoński, Bukowska, Czabała, 2012). Twórcą tej inicjatywy był Marek Kotański - polski psycholog, terapeuta, organizator wielu przedsięwzięć, które miały na celu zwalczanie patologii społecznej i pomaganie osobom uzależnionym od alkoholu, narkotyków, zakażonym wirusem HIV, byłym więźniom czy osobom bezdomnym. MONAR podpisał porozumienie z Ministerstwem Zdrowia dotyczące zasad prowadzenia i finansowania programów profilaktycznych i leczenia narkomanii. W ciągu kilku lat zostało utworzonych jedenaście podobnych ośrodków, których głównym zadaniem było utrzymanie pacjentów w trzeźwości, wparcie terapią środków farmaceutycznych oraz oddziaływanie metodą społeczności terapeutycznej.

Lata 80. charakteryzowały się wzrostową liczbą problemów związanych z narkomanią we wszystkich sferach życia społecznego. Jak się wydaje, typy zachowań narkotykowych w pierwszych trzech dekadach II połowy XX wieku były pochodną silnych wpływów subkultury hippisowskiej oraz subkultur środowisk społecznych. Wraz z otwarciem się Polski na świat po 1989 roku następowało szybkie zróżnicowanie zachowań narkotykowych, jak również pojawienie się nowych problemów (Jędrzejko, 2009; por. Pierzchała, 2010; 2013). Dostrzeżenie narkomanii rozumianej jako problem społeczny datuje się na czas przełomu ustrojowego po 1989 roku i wiąże się przede wszystkim ze wzrostem podaży narkotyków, na co kluczowy wpływ miał rozwój zorganizowanej przestępczości (Jędrzejko, 2009). 
Jak wskazują M. Jędrzejko oraz M. Cabalski, czynniki mające wpływ na pojawienie się i rozwój zjawiska narkomanii są następujące: podaż (dostępność) narkotyków, wzorce społeczne; model i efektywność profilaktyki; potencjał służb zwalczania przestępczości narkotykowej; wzorce kulturowe; model reakcji prawnych; skala zjawisk innych patologii społecznych; narkomania w najbliższej rodzinie.

Narkomania jest zaliczana do zjawisk patologii społecznej o szerokim zasięgu i rosnącej dynamice rozwojowej. Nie jest zjawiskiem nowym, jednak obecnie wielu specjalistów ocenia, że jest najgroźniejszą współczesną patologią społeczną. Tendencje rozwojowe narkomanii kształtuje wiele czynników, do których należy zaliczyć: zwiększenie podaży narkotyków wskutek szybkiego rozwoju ich produkcji i dystrybucji, społeczną destygmatyzację zażywania narkotyków, interakcje pomiędzy narkomanią a innymi zjawiskami, nieustanne poszerzanie się gamy naturalnych i syntetycznych środków psychoaktywnych (Jędrzejko, 2006).

Problem narkomanii ma charakter interdyscyplinarny o szerokim zasięgu. Znajduje się on w polu zainteresowań różnych służb, takich jak lecznictwo, oświata, pomoc społeczna, organy ścigania i wymiaru sprawiedliwości. Każda z nich styka się z tym zjawiskiem od innej strony (Sołtysiak, KowalczykJamnicka, 2007).

Współcześnie narkomania postrzegana jest jako patologia społeczna, zajmując miejsce obok przestępczości, prostytucji czy pracoholizmu. Określana jako uzależnienie chemiczne, prowadzi nie tylko do konsekwencji społecznych, zdrowotnych czy moralnych, lecz także prawnych (por. Pierzchała, Cekiera, 2008; 2009).

Narkomania w Polsce dotyczy głównie młodzieży i najczęściej występuje w miastach. Najbardziej zagrożone są duże aglomeracje miejskie lub miasta położone w niewielkiej od nich odległości oraz regiony turystyczne. Większość osób odurzających się stanowią mężczyźni o niskim wykształceniu, nie pracujący, nie uczący się, o pochodzeniu robotniczym, z rodzin dysfunkcyjnych i patologicznych. Narkomania w Polsce różni się od narkomanii w innych państwach głównie dostępnością środków odurzających, gdyż ich oferta jest wciąż mniej zróżnicowana i uboższa niż w Europie Zachodniej czy w USA (por. Pierzchała, Cekiera, 2008; 2009). Najczęściej używane są dostępne i tańsze opiaty rodzimej produkcji i środki wziewne oraz leki uspokajające i nasenne. Problemem społecznym jest zatem głównie zależność typu morfinowego, wywołująca bardzo silny nałóg psychiczny i fizyczny, postępujący w bardzo szybkim tempie. Dużą popularność w Polsce zdobyły leki uspokajające i nasenne, które często są używane przez uzależnionych od opiatów w celu wzmocnienia efektu ich działania lub jako zamiennik w przypadku ich braku. Poważny problem stanowi także - głównie wśród nastolatków i dzieci - odurzanie się środkami 
wziewnymi, które nadużywane w dłuższym okresie powodują zależność psychiczną, ale także trwałe i poważne uszkodzenie układu nerwowego. Polska jest obecnie krajem tranzytowym dla handlarzy narkotyków, nie stanowiąc znaczącego rynku zbytu. Większość narkomanów pozostaje dalej „samowystarczalna", wykorzystując środki i surowce pochodzenia krajowego (Nowak, Wysocka, 2001; Pierzchała, 2018).

\section{KRYMINOGENNY ASPEKT NARKOMANII}

Przestępczość narkotykowa jako zjawisko ma tak wiele aspektów, że trudno jest je sprecyzować, odnaleźć odpowiednią definicję tego zagadnienia. Dokonując próby wyjaśnienia pojęcia zjawiska przestępczości związanej z narkotykami, przyjęto pewien podział, obejmujący przestępstwa popełnione pod wpływem narkotyków, przestępstwa popełnione w celu zdobycia środków finansowych na zakup narkotyków, przestępstwa popełnione w kontekście funkcjonowania nielegalnych rynków narkotykowych oraz przypadki naruszania prawa antynarkotykowego.

$\mathrm{Z}$ metodologicznego punktu widzenia związek między narkomanią a przestępczością powinien być postrzegany według wyczerpującego systemowego schematu znaczenia, jakie dany element rzeczywistości (w tym przypadku - używanie środków narkotycznych) ma dla innego elementu rzeczywistości (w tym przypadku - przestępstwa). Schemat ten zakłada, że związek przyczynowo-skutkowy może zawierać się w następujących sytuacjach:

1. Bezpośredni związek między potrzebą zdobycia środka odurzającego a kradzieżą tego środka poprzez fałszowanie recept, szantażowanie w celu zdobycia środka, zmuszanie osób trzecich pod groźbą przemocy fizycznej do wydania bądź zdobycia pożądanego środka. W innym ujęciu - od strony osoby samowolnie produkującej, handlującej, przemycającej dostarczającej innych środków odurzających - związek ten zasadza się na świadomości, że dany środek odurzający jest pożądany. Działa tu prawo popytu i podaży na środki, gdzie bezpośrednią przyczyną popełniania przestępstwa jest występowanie narkomanii jako zjawiska uznanego za negatywne i wobec tego profilaktycznie hamowanego przez reglamentację substancji toksycznych.

2. Drugi rodzaj związku między narkomanią i przestępczością polega na wzmacniającym motywację do popełnienia przestępstwa środka narkotykowego. Jest to sytuacja, gdy osoba, która ma już motywację do popełnienia czynu zabronionego prawem, używa jakiegoś środka narkotycznego w celu pobudzenia się do działania tu i teraz, rozluźnienia i rozproszenia obaw, nadania swojemu działaniu śmiałości. Występuje tu pełna świadomość działania tego środka. 
3. Trzecim rodzajem związku między narkomanią a przestępstwem jest wspomagająca rola narkotyku w działaniu przestępczym. Do tej kategorii należą czyny, które człowiek będący pod działaniem substancji odurzającej popełnia wpółświadomie lub nieświadomie. Do grupy tej można zaliczyć czynne napaści, zabójstwa, zgwałcenia, naruszenie porządku publicznego, powodowanie wypadków komunikacyjnych. W zależności od rodzaju przyjętego narkotyku reakcje są różne; występuje też zależność między ilością zażytego środka a rodzajem reakcji oraz osobniczą odpornością organizmu a reakcją organizmu na użyty środek. Wyzwalające się reakcje psychomotoryczne, szczególnie gdy narkotyzowanie odbywa się w grupie, mają dość dużą nośność kryminogenną i wiktymogenną. Człowiek pozbawiony normalnie funkcjonującego aparatu regulacji zachowań łatwo staje się sprawcą lub ofiarą przestępstwa. Dotyczy to praktycznie wszystkich rodzajów czynów przestępczych, których dokonanie nie wymaga długiego przygotowania; narkotyki bowiem działają tylko przez pewien określony czas i po upływie tego czasu następuje zazwyczaj spadek aktywności - aż po depresyjne otępienie (Hołyst, 2016, s. 471).

Obowiązująca ustawa o przeciwdziałaniu narkomanii z dnia 29 lipca 2005 roku (Dz. U. nr 179, poz. 1485) zawiera uregulowania dotyczące przestępstw związanych z narkotykami. Zapisy ustawowe odnoszą się do poszczególnych kategorii przestępczości i obejmują przestępstwa przeciwko postanowieniom ustawy o przeciwdziałaniu narkomanii.

Wspomniana ustawa z 29 lipca 2005 r. o przeciwdziałaniu narkomanii określa:

4) Zasady i tryb postępowania w zakresie przeciwdziałania narkomanii.

5) Zadania i uprawnienia organów administracji rządowej i jednostek samorządu terytorialnego oraz innych podmiotów w zakresie przeciwdziałania naruszeniom prawa dotyczącego obrotu, wytwarzania, przetwarzania, przerobu i posiadania substancji, których zażywanie może doprowadzić do narkomanii.

6) Organy właściwe do wykonania:

a) Rozporządzenia (WE) Parlamentu Europejskiego i Rady nr 273/2004 z 11 lutego 2004 r. w sprawie prekursorów narkotykowych (Dz. Urz. WE L 047 z 18.02.2004);

b. Rozporządzenia (WE) Rady 111/2005 z 22 grudnia 2004 r. określającego zasady nadzorowania handlu prekursorami narkotyków między Wspólnotą a państwami trzecimi (Dz. Urz. WE L 22.01.2005);

c. Kary za nieprzestrzeganie przepisów ustawy i rozporządzeń wymienionych w pkt. 3 (Hołyst, 2016).

Zgodnie z ustawą o przeciwdziałaniu narkomanii, karalne jest: 
- wytwarzanie, przetwarzanie albo przerabianie, wbrew przepisom ustawy, środków odurzających lub substancji psychotropowych;

- wyrabianie, posiadanie, przechowywanie, zbycie lub nabycie przyrządów mogących służyć do niedozwolonego wytwarzania lub przerobu substancji psychotropowych;

- przywożenie z zagranicy, wywożenie lub tranzyt środków uznanych za odurzające lub substancji psychotropowych;

- wprowadzanie do obrotu, wbrew przepisom ustawy, środków odurzających, substancji psychotropowych, mleczka makowego lub słomy makowej albo uczestniczenie w takim obrocie;

- udzielanie innej osobie, wbrew przepisom ustawy, środka odurzającego lub substancji psychotropowej albo nakłanianie do użycia takiego środka lub substancji, lub ułatwianie takiego użycia zagrożone jest karą pozbawienia wolności do lat trzech;

- wytwarzanie, przetwarzanie, przerabianie, przywożenie z zagranicy, wywożenie za granicę;

- przewożenie w tranzycie, nabywanie, posiadanie lub przechowywanie prekursorów, wbrew przepisom ustawy, w celu niedozwolonego wytworzenia środka odurzającego lub substancji psychotropowej;

- posiadanie środków odurzających lub substancji psychotropowych(Ustawa, 2005).

Przestępstwa związane z narkotykami można rozpatrywać w czterech następujących kategoriach:

1. przestępstwa psychofarmakologiczne, popełniane pod wpływem substancji psychoaktywnej, w wyniku przyjęcia dużej dawki substancji lub długotrwałego jej zażywania;

2. kompulsywne przestępstwa o charakterze ekonomicznym, popełniane w celu zdobycia pieniędzy (lub narkotyków) dla zaspokojenia głodu narkotykowego;

3. przestępstwa o charakterze ogólnym, popełniane w ramach funkcjonowania rynku narkotyków nielegalnych jako część interesów związanych z zaopatrzeniem w narkotyki, ich dystrybucją oraz zażywaniem;

4. przestępstwa przeciwko prawu antynarkotykowemu, popełniane przeciwko przepisom antynarkotykowym (oraz innym przepisom powiązanym) (Struzik, 2007, s. 5). 


\subsection{PRZESTĘPSTWA PSYCHOFARMAKOLOGICZNE}

Model psychofarmakologiczny zakłada, iż zażycie dużej dawki substancji psychoaktywnej lub długotrwałe używanie narkotyku może powodować agresję i przemoc. Ponadto skutki użycia narkotyków mogą objawiać się m.in. pobudliwością, drażliwością, lękami, rozhamowaniem, silnymi zmianami nastrojów, zaburzeniami kognitywnymi i ograniczoną zdolnością oceny sytuacji. Wszystkie powyższe okoliczności mogą prowadzić do zachowań przestępczych. „Jednocześnie do tej kategorii trzeba również zaliczyć przestępstwa będące wynikiem zażywania narkotyków przez ofiarę przestępstwa, takie jak napaść seksualna, popełniona, gdy ofiara jest pod wpływem substancji psychoaktywnej, oraz kradzieże czy rozboje, które stają się możliwe, gdy ofiara traci sprawność z powodu zażycia narkotyków" (Struzik, 2007). Nie można jednoznacznie stwierdzić, które substancje psychoaktywne mają uniwersalne właściwości kryminogenne, ponieważ zachowanie człowieka pod wpływem narkotyków jest uwarunkowane zarówno indywidualnie, jak i środowiskowo. Badania wykazują jednak istotny wpływ narkotyków (począwszy od środków stymulujących, po opiaty i środki uspokajające) na nasilanie zachowań gwałtownych, często prowadzących do czynów przestępczych (Struzik, 2007).

\subsection{KOMPULSYWNE PRZESTĘPSTWA O CHARAKTERZE EKONOMICZNYM}

Czyny przestępcze popełniane są często w celu uzyskania środków finansowych potrzebnych na zaspokojenie głodu narkotykowego. W ramach tych działań mogą występować takie przestępstwa, jak: sprzedaż narkotyków lub prostytucja (w przypadku, gdy są niezgodne z prawem), przestępstwa związane z kradzieżą (np. kradzież sklepowa, rozbój, kradzież z włamaniem), fałszowanie recept i włamania do aptek przez osoby uzależnione od narkotyków (Struzik, 2007).

Podczas gdy określenie „kompulsywny” wskazuje, że konieczny jest pewien stan uzależnienia, to sprawcami w tej kategorii są wszyscy, którzy muszą finansować zażywanie narkotyków za pomocą nielegalnych dochodów. Obraz tych przestępstw jest jednak w dużej mierze uwarunkowany wzorem używania substancji, sytuacją społeczno-ekonomiczną oraz stylem życia osoby (Struzik, 2007). 


\subsection{PRZESTĘPSTWA O CHARAKTERZE OGÓLNYM}

Przypadki przestępstw o charakterze ogólnym dotyczą głównie czynów z użyciem przemocy (np. napadów, zabójstw), występujących w ramach funkcjonowania rynku nielegalnych narkotyków, i związane są ze sprzedażą, dystrybucją oraz zażywaniem tych substancji. Przemoc jest bowiem stosowana jako narzędzie kontroli, szczególnie w sytuacjach takich, jak spory o terytorium, kary za oszustwo, inkasowanie należności i starcia z policją. Przestępstwa o charakterze ogólnym mogą obejmować także korupcję w przedsiębiorstwach, administracji rządowej, systemach bankowych.

Warto zauważyć, iż może zaistnieć efekt wzajemnego wzmacniania między działalnością przestępczą a zażywaniem narkotyków: osoby związane z subkulturą przestępczą są w większym stopniu zagrożone problemami narkotykowymi, natomiast osoby problemowo zażywające narkotyki są bardziej zagrożone zaangażowaniem się w działalność przestępczą (Struzik, 2007).

\subsection{PRZESTĘPSTWA PRZECIWKO PRAWU ANTYNARKOTYKOWEMU}

Przestępstwa przeciwko prawu antynarkotykowemu obejmują przypadki naruszenia przepisów dotyczących narkotyków, jak zażywanie, posiadanie, uprawa, produkcja, handel narkotykami i ich prekursorami oraz przestępstwa związane z kierowaniem pojazdami pod wpływem narkotyków. Związek między narkotykami i przestępczością w tym przypadku wynika $\mathrm{z}$ definicji przyjętej w przepisach prawnych, a nie z wpływu jednego zachowania na drugie. Podstawą warunkującą zaistnienie tego typu przestępstw jest bowiem zakaz dotyczący grupy nielegalnych substancji psychoaktywnych (Struzik, 2007, s. 6).

Badania nad związkiem między zażywaniem narkotyków/handlem narkotykami i przestępczością przeprowadzano głównie na terenie USA. Próbą badawczą były najczęściej osoby przebywające $\mathrm{w}$ odosobnieniu, w areszcie lub poddające się leczeniu odwykowemu. Analizy schematów łamania prawa ukazują obraz złożonych zależności między narkotykami a działalnością przestępczą. Bardzo trudne okazało się oszacowanie liczby przestępstw związanych z narkotykami. Powodem był fakt, iż wiele z nich nie zostaje zarejestrowanych, a oficjalne dane statystyczne nie oddają w pełni skali problemu. Podsumowując, należy zaznaczyć, że „,[..]wprowadzone kategorie i modele teoretyczne przestępstw związanych z narkotykami mogą wzajemnie się pokrywać. Podział ten jednak 
umożliwia dokonanie konceptualizacji przestępstw związanych z narkotykami i ułatwia przeprowadzenie porównań" (Struzik, 2007).

W państwowym systemie bezpośredniego zwalczania przestępczości narkotykowej główną rolę odgrywa Policja. Oprócz niej do przeciwdziałania przestępstwom narkotykowym zobowiązanych jest kilka innych służb rządowych. Odpowiednie działania, zwłaszcza w zakresie operacyjno-rozpoznawczym, prowadzą Agencja Bezpieczeństwa Wewnętrznego, Centralne Biuro Antykorupcyjne, Straż Graniczna, Generalny Inspektorat Służby Celnej i Żandarmeria Wojskowa (Jędrzejko, 2006).

W strukturze organizacyjnej Policji podział zadań jest następujący:

- Służba Prewencyjna - zwłaszcza jej jednostki terenowe - realizuje podstawowe rozpoznanie zjawiska narkomanii w ramach rutynowych czynności o charakterze profilaktycznym. Biuro Prewencji i Ruchu Drogowego Komendy Głównej Policji oraz jego ogniwa na szczeblu wojewódzkim i powiatowym prowadzą przedsięwzięcia profilaktyczne, podejmowane w ramach bieżących kontaktów ze społeczeństwem i programów ogólnokrajowych.

- Służba Kryminalna - opowiada za prowadzenie rozpoznawania przez czynności operacyjne oraz za ściganie sprawców przestępstw narkotykowych w toku prowadzonych dochodzeń i śledztw. Działania jednostek służby kryminalnej koncentrują się przede wszystkim na ujawnieniu lokalnych ośrodków produkcji narkotyków, ich rozprowadzania i nielegalnego posiadania oraz ściganiu przestępczości narkotykowej mniejszej wagi.

- Centralne Biuro Śledcze Komendy Głównej Policji (CBŚP) - zajmuje się rozpoznawaniem i zwalczaniem przestępczości zorganizowanej. Przedmiotem działań biura są międzynarodowe i krajowe aspekty przestępczości narkotykowej: produkcja narkotyków i obrót nimi na dużą skalę oraz wszelkie postaci przemytu narkotyków w znacznych ilościach. CBŚP ujawnia i likwiduje laboratoria narkotyków syntetycznych oraz współpracuje z instytucjami i służbami zagranicznymi w zwalczaniu przestępstw narkotykowych. Szczególną powinnością CBŚP jest neutralizacja zorganizowanych struktur przestępczych, zdominowanych przez przedstawicieli mniejszości etnicznych. Na CBŚP ciąży też obowiązek opracowania i wdrażania policyjnej strategii zwalczania przestępczości narkotykowej oraz szkolenia policjantów w zakresie przeciwdziałania zjawisku narkomanii (Jędrzejko, 2006). 


\section{NARKOBIZNES}

Rynek narkotykowy w Polsce upodobnia się do rynku narkotykowego w Europie Zachodniej i włącza się w działalność międzynarodowego narkobiznesu. Jest on jednym z elementów nasilającej się w ostatnim czasie przestępczości zorganizowanej.

Narkotyki występujące na nielegalnym rynku w Polsce pochodzą z wielu źródeł. Marihuana, haszysz, ecstasy i LSD są sprowadzane na rynek głównie z Belgii, Holandii i Niemiec (Hołyst, 2016, s. 466).

Pojęcie przestępczości zorganizowanej pojawiło się w kryminologii po II wojnie światowej na oznaczenie pewnej formy przestępczości zbiorowej uznawanej za szczególnie niebezpieczną. Chodziło o rozprzestrzenianie się międzynarodowych powiązań między przestępcami działającymi dotąd w poszczególnych krajach, a także o przenikanie przestępców do świata biznesu i polityki. Usiłowano zatem nadać tej nazwie umowne znaczenie, gdyż inaczej zawierałaby ona sugestię, że poza jej zakresem pozostają zjawiska, które należy określić jako „przestępczość niezorganizowana”. Wynikałoby stąd istotne nieporozumienie, ponieważ ludzie, aby osiągać założone cele, zmuszeni są w każdej dziedzinie aktywności do współdziałania. Polega ono na podziale zadań, wymuszającym z kolei specjalizację oraz określenie wzajemnych praw i obowiązków. Współdziałanie przebiega zatem w sposób zorganizowany, a choć poziom zorganizowania bywa bardzo zróżnicowany, elementy organizacji przy współdziałaniu występują zawsze. Oczywiste jest zaś, że ludzie współdziałają ze sobą również przy popełnianiu przestępstw, wobec czego do przestępczości zorganizowanej należałoby zaliczyć każdy wypadek przestępczego współdziałania, choćby chodziło o doraźne współdziałanie dwóch osób (Błachut, Gaberle, Krajewski, 2014).

Nieporozumień i rozbieżności interpretacyjnych dotyczących pojęcia przestępczości zorganizowanej nie uniknięto, bowiem nie sprecyzowano przedmiotu, do którego miało się ono odnosić. Od początku nie było jasne, czy chodzi o „,instytucjonalizację przestępczości”, czyli tworzenie stałych struktur trudniących się działalnością przestępczą, czy też o organizowanie działań przestępczych, bez względu na to, czy prowadzi to do wytworzenia choćby względnie trwałych struktur. Stąd poza dyskusją jest jedynie to, że przestępczość zorganizowana jest działalnością zespołową, a członkowie takiego zespołu połączeni są więzią pozwalającą im na skuteczniejsze popełnianie przestępstw. Sporne są natomiast następujące kwestie:

(1) struktura zespołu - czy musi być co najmniej dwupoziomowa (hierarchiczna), czy wystarczy jednopoziomowa; 
(2) trwałość zespołu - czy konieczne jest nastawienie na ciągłe popełnianie przestępstw, czy wystarczy porozumienie w celu popełnienia choćby jednego przestępstwa;

(3) zakres powiązań zespołu - czy konieczne jest powiązanie z osobami ze świata polityki, administracji publicznej lub gospodarki, czy też nie jest to niezbędne (Błachut, Gaberle, Krajewski, 2014).

W zależności od tego, które z tych przeciwstawnych cech uzna się za konstytutywne dla przestępczości zorganizowanej, dochodzi się do jednego z dwóch odmiennych modeli tej przestępczości:

(1) do modelu wąskiego („mafijnego”) - zespół o strukturze hierarchicznej, powołany do prowadzenia ciągłej działalności przestępczej, z rozbudowanymi powiązaniami ze sferą gospodarki lub polityki;

(2) do modelu szerokiego („grupowego”) - zespół o dowolnej strukturze, utworzony w celu popełnienia choćby jednego przestępstwa, o dowolnym zakresie powiązań (Błachut, Gaberle, Krajewski, 2014).

Modele te wyznaczają krańce pewnego ciągu, między którymi mogą się mieścić modele „pośrednie” o różnym nasileniu wskazanych cech.

Najczęściej przywoływanymi przez specjalistów cechami przestępczości zorganizowanej są cztery jej elementy: istnienie zorganizowanej i stabilnej hierarchii w strukturach przestępczych; osiąganie korzyści z działalności przestępczej; stosowanie siły i zastraszania; posługiwanie się korupcją dla zapewnienia sobie bezkarności (Zięba, 2008). W literaturze tematu przestępczość zorganizowana jest najczęściej łączona z takimi zagrożeniami, jak gangi, narkotyki, przemyt, handel ludźmi, pranie brudnych pieniędzy, prostytucja, mafia.

Od co najmniej kilkunastu lat następuje też głęboka przebudowa świata przestępczego zajmującego się handlem narkotykami - jest on coraz bardziej międzynarodowy i powiązany z legalnymi typami działania gospodarczego oraz zdolny do szybkich modyfikacji w zakresie form i metod. Umieszczenie zagrożeń narkotykowych w tym raporcie świadczy o tym, że jest to problem realny, o szerokich konsekwencjach prawnych, ekonomicznych, społecznych i zdrowotnych. Istniejące i dostępne badaczom tej problematyki opracowania wskazują na dynamiczny rozwój przestępczości narkotykowej, co związane jest z innymi typami działań przestępczych. Podkreślenia wymaga także, że wszelkie próby diagnozowania zjawiska przestępczości narkotykowej jako odrębnej formy przestępstw obarczone są dużym ryzykiem.

Jego tło jest związane z trzema kluczowymi kwestiami.

1. Według dostępnych opracowań polskich (Agencji Bezpieczeństwa Wewnętrznego, Policji, Żandarmerii Wojskowej, Straży Granicznej oraz innych 
polskich służb uczestniczących w realizacji ustawowych zadań wynikających z ustawy o przeciwdziałaniu narkomanii), w zasadzie nie istnieją organizacje przestępcze zajmujące się tylko przestępczością narkotykową. Narkobiznes jest częścią szerszych zorganizowanych działań przestępczych, często o szerokich międzynarodowych powiązaniach:

2. Skala zjawiska - w tym przejęcia narkotyków, zatrzymania dealerów, likwidacja nielegalnych laboratoriów - są obarczone statusem wysokiego niedoszacowania (według różnych źródeł instytucje bezpieczeństwa zatrzymują nie więcej niż 10-20\% narkotyków wprowadzanych na rynek);

3. Konsekwencje narkobiznesu powinny być identyfikowane w holistycznym ujęciu, także przez szkody ekonomiczne (szara strefa, koszty leczenia i rehabilitacji osób uzależnionych); ludzkie (przemoc, prostytucja, handel ludźmi, niższe szanse zawodowe) i zdrowotne (choroby) (Jędrzejko, 2013).

Powyższe tezy należałoby uzupełnić o kluczową kwestię dostrzeganą przez badaczy tej problematyki. Przestępczość narkotykowa jest jednym z najbardziej dynamicznych i najlepiej zorganizowanych przejawów łamania prawa, a w części producencko-dystrybucyjnej niezwykle niebezpieczna ze względu na ogromne zyski finansowe, wzmacniające świat przestępczy. Można przyjąć, że sfera nielegalnego handlu narkotykami to ok. 2-4 mld euro rocznie, z czego mniej więcej 30\% stanowi zysk grupy nie większej niż kilkaset osób stanowiących hierarchię świata przestępczego (Jędrzejko, 2013).

Chociaż problemy narkotykowe, w tym rozwój przestępczości narkotykowej, są w wielu krajach i regionach bardzo podobne, to występują też widoczne różnice, które zauważyć można poprzez: aktywność grup przestępczych, podaż określonych rodzajów narkotyków, krajową politykę narkotykową, społeczno-kulturowy kontekst używania narkotyków oraz opinii społecznych na temat legalizacji nielegalnych substancji.

\section{STRUKTURA I DYNAMIKA PRZESTĘPCZOŚCI NARKOTYKOWEJ (MINISTERSTWO SPRAW WEWNĘTRZNYCH I ADMINISTRACJI, 2017)}

Analiza informacji statystycznych o przestępczości narkotykowej wskazuje, że mamy do czynienia ze stałym wzrostem i nasilającym się rozwojem nielegalnego rynku narkotykowego. Zarówno popyt, jak i podaż środków odurzających pozostaje dużym problemem społecznym w całej Europie. „Europejski raport narkotykowy na rok 2016. Tendencje i osiągnięcia" informuje, że nieco ponad jedna czwarta populacji dorosłych Europejczyków (ponad $88 \mathrm{mln}$ osób dorosłych) przynajmniej raz w życiu używała narkotyków. 
W Polsce narkomania rozwija się szczególnie dynamicznie w dużych aglomeracjach miejskich, takich jak Warszawa, Katowice, Trójmiasto, Wrocław, Kraków i Szczecin. Można także zaobserwować ekspansję narkomanii do mniejszych miast, ośrodków turystycznych i strefy przygranicznej (Hołyst, 2016). Obecnie rynek środków odurzających w Polsce, tj. rodzaje i dostępność narkotyków, nie różni się od rynku w Stanach Zjednoczonych i Europie Zachodniej. Oferta środków uzależniających jest bogata i zróżnicowana (Hołyst, 2016).

Dynamika przestępczości narkotykowej w Polsce wykazuje tendencję wzrostową. Polska staje się rynkiem zbytu klasycznych narkotyków. Rozpoznaje się coraz silniejsze powiązania polskich środowisk przestępczych z innymi krajami, m.in. w zakresie:

1) Produkcji narkotyków syntetycznych - poważnym i coraz bardziej niebezpiecznym problemem, bulwersującym opinię międzynarodową, jest nielegalna produkcja narkotyków syntetycznych w Polsce i ich przemyt głównie do Niemiec i państw skandynawskich. Ocenia się, że na naszym terytorium działa kilkanaście laboratoriów nielegalnie produkujących amfetaminę zarówno na potrzeby rynku wewnętrznego, jak i na „eksport”. Rozwój produkcji tego środka zaowocował spadkiem ceny i coraz szerszym kręgiem osób odurzających się amfetaminą;

2) Tranzytu i przemytu - międzynarodowe organizacje przestępcze coraz częściej wykorzystują terytorium Polski do przemytu i tranzytu narkotyków;

3) Udziału obywateli polskich w przemycie narkotyków na tereny innych państw (Hołyst, 2016).

Głównym miejscem dystrybucji narkotyków, podobnie jak w latach ubiegłych, pozostają miejsca publiczne, takie jak ulice, bloki mieszkalne, placówki edukacyjne, tereny przyległe do centrów handlowych, przystanki komunikacji miejskiej, lokale rozrywkowe, dyskoteki oraz pustostany i miejsca odosobnione (np. parki). Do kontaktów kupujący - sprzedający niejednokrotnie służą telefony komórkowe i komunikatory internetowe, a przekazywane informacje są przesyłane w sposób zakamuflowany i znany tylko rozmówcom. Często kupujący nie ma bezpośredniego wizualnego kontaktu ze sprzedającym (po zamówieniu narkotyku sprzedający wskazuje miejsce, w którym o umówionej godzinie kupujący zostawia pieniądze, a następnie udaje się tam dealer i pozostawia zamówione narkotyki, zabierając gotówkę) (Hołyst, 2016).

Dystrybucją narkotyków zajmują się grupy przestępcze, osoby wielokrotnie karane za tego typu przestępstwa, a także osoby dotychczas niekarane, które uzyskały środki odurzające z własnej produkcji (np. konopie inne niż włókniste), a następnie rozprowadzają je głównie wśród znajomych. Narkotykami handlują osoby $\mathrm{z}$ różnych środowisk społecznych i w różnym wieku. Zjawisko handlu narkotykami 
jest związane bezpośrednio z bardzo dużym popytem na tego rodzaju substancje, jak również ze względu na szybki i duży przychód osób je dystrybuujących. Pośrednio znaczenie ma sytuacja społeczno-ekonomiczna, w tym np. bezrobocie.

W 2016 roku jednostki Policji odnotowały duże zainteresowanie i coraz częstsze pojawianie się na rynku „dopalaczy”, czyli środków zastępczych. Najpopularniejszym sposobem zakupu tego typu substancji jest Internet, ale funkcjonują także sklepy stacjonarne. W 2016 roku Policja i Państwowa Inspekcja Sanitarna organizowały skoordynowane akcje skierowane przeciwko punktom sprzedaży stacjonarnej dopalaczy w całej Polsce (łącznie zlikwidowano 449 takich placówek). Wzięło w nich udział około 1876 policjantów i około 1000 pracowników Inspekcji. Zatrzymano 154 osoby i zabezpieczono ponad $236 \mathrm{~kg}$ oraz prawie 15,5 tys. sztuk opakowań różnych substancji psychoaktywnych.

Policja nie ma możliwości prawnych zabezpieczania substancji chemicznych niewpisanych do załączników ustawy o przeciwdziałaniu narkomanii jako substancji objętych kontrolą ustawową i ścigania osób odpowiedzialnych za ich dystrybucję. Objęcie kontrolą ustawową nowo rozpoznanej substancji chemicznej powoduje pojawienie się na rynku nowych środków, które ze względu na skład chemiczny nie podlegają kontroli w ramach ustawy o przeciwdziałaniu narkomanii.

Według Policji najpoważniejsze zagrożenia to:

- Rosnąca liczba upraw konopi innych niż włókniste i wytwarzanie z nich marihuany.

- Rosnący rynek „dopalaczy”. W 2010 roku do ustawy o przeciwdziałaniu narkomanii wprowadzono regulacje związane ze środkami zastępczymi, które spowodowały ograniczenie ich podaży do roku 2014. Od roku 2015 zjawisko podaży nowych substancji psychoaktywnych ponownie się nasiliło, osiągając apogeum w czerwcu i lipcu 2015 r., co było związane z nowelizacją ustawy o przeciwdziałaniu narkomanii i wpisaniem na listę substancji psychotropowych i środków odurzających ponad 160 związków chemicznych. Tego rodzaju substancje są importowane z krajów azjatyckich (Indie, Chiny, Hongkong).

- Produkcja amfetaminy, która od kilku lat utrzymuje się na stabilnym poziomie, stawiająca Polskę na czołowym miejscu wśród producentów tego narkotyku w Europie, jak również przemyt narkotyków syntetycznych (amfetaminy płynnej i w postaci proszku z krajów Europy Zachodniej - Belgii i Holandii).

- Import prekursorów i preprekursorów do produkcji narkotyków syntetycznych z państw azjatyckich. Przemyt (z i do Polski) różnych substancji chemicznych wykorzystywanych do produkcji prekursorów i narkotyków.

- Działalność polskich zorganizowanych grup przestępczych w Europie Zachodniej (głównie w Hiszpanii, ale także w Holandii, Wielkiej Brytanii i krajach skandynawskich). 
- Produkcja narkotyków syntetycznych przy wykorzystaniu niekontrolowanych substancji chemicznych.

- Wzrost produkcji metamfetaminy z wykorzystaniem leków zawierających pseudoefedrynę, pozyskiwanych z legalnie dostępnych na rynku lekarstw oraz nowe źródła pochodzenia preparatów medycznych.

W 2016 roku przestępczość narkotykowa rozpoznawana przez Straż Graniczną utrzymywała się na podobnym poziomie jak w poprzednich latach. W dalszym ciągu jako osoby zaangażowane w prowadzenie przestępczości narkotykowej identyfikowano:

- obywateli Polski przemycających do RP narkotyki w średnich ilościach, służących do zaopatrzenia lokalnego rynku;

- obywateli Azji Wschodniej, zaangażowanych w produkcję metamfetaminy na szeroką skalę; wyprodukowany na terytorium Polski narkotyk następnie trafiał na rynki Europy Zachodniej;

- obywateli byłych republik radzieckich, członków międzynarodowych zorganizowanych grup przestępczych, którzy przemycali hurtowe ilości narkotyków, Polskę traktując jako kraj tranzytowy.

- Głównymi czynnikami wpływającymi na wzrost zagrożeń przestępczością narkotykową w 2016 roku były:

- coraz większe możliwości polskich zorganizowanych grup przestępczych w zakresie szerokich kontaktów międzynarodowych, zarzadzanie przez nie coraz większymi siłami i środkami, w tym finansowymi oraz sprzętowymi;

- brak kontroli granicznej w strefie Schengen, ułatwiający swobodne przemieszczanie się sprawców przestępstw narkotykowych drogą lądową;

- liberalna polityka narkotykowa w państwach sąsiednich (Czechy) oraz w Holandii, dająca możliwość łatwego wejścia w posiadanie narkotyków syntetycznych i pochodnych marihuany;

- traktowanie przez zorganizowane grupy przestępcze terytorium Polski jako kraju tranzytowego na szlaku z państw Europy Zachodniej do Rosji oraz z kierunków bliskiego Wschodu do krajów Europy Zachodniej.

- Zgodnie z informacjami Agencji Bezpieczeństwa Wewnętrznego grupy przestępcze trudniące się przestępczością narkotykową mają w większości charakter międzynarodowy. Na rynek europejski naturalne narkotyki trafiają głównie z krajów Ameryki Południowej i Azji. Narkotyki syntetyczne często są produkowane w krajach europejskich, m.in. w Polsce. W rozpoznawanych przez ABW grupach narkotykowych Polacy odgrywali głównie rolę kurierów/ przemytników, dystrybutorów oraz producentów prekursorów.

Jednym z zagrożeń zidentyfikowanych przez ABW jest działalność międzynarodowych zorganizowanych azjatyckich grup przestępczych łączących 
przestępczość gospodarczą (np. przemyt towarów, przestępczość podatkową) $\mathrm{z}$ aktywnością w narkobiznesie. Utrzymująca się w ostatnich latach fala migracji do Europy może pociągnąć za sobą wzrost zagrożeń związanych z międzynarodową przestępczością zorganizowaną, w tym handlem narkotykami. W 2016 roku w zakresie zwalczania przestępczości narkotykowej ABW współpracowała z Policją i Strażą Graniczną (m.in. w lokalizacji plantacji marihuany, wykrywaniu przemytu amfetaminy).

Do najpoważniejszych, zdaniem Krajowej Administracji Skarbowej, zjawisk należy:

- powstawanie wyspecjalizowanych sklepów internetowych oferujących do sprzedaży środki odurzające i środki zastępcze, wykorzystujące do komunikacji z klientem kodowane sieci komputerowe TOR (The Onion Router);

- zagrożenie dotyczące nielegalnego sprowadzania i dystrybucji produktów leczniczych o nieznanym składzie (produkty lecznicze wczesnoporonne, produkty lecznicze na odchudzanie, produkty lecznicze na potencję);

- próby importu legalnych substancji i związków chemicznych oraz import maszyn i urządzeń laboratoryjnych, wykorzystywanych następnie do produkcji prekursorów, środków zastępczych i środków odurzających;

- próby nielegalnego wprowadzania na rynek europejski produktów leczniczych zawierających pseudoefedrynę, służących następnie do produkcji metamfetaminy.

W 2016 roku wszczęto 31013 postępowań przygotowawczych o przestępstwa narkotykowe, co oznacza wzrost ich liczby w porównaniu z 2015 rokiem o 2,1\% (z 30 389). W 2016 roku Policja stwierdziła 60400 przestępstw z ustawy o przeciwdziałaniu narkomanii, co oznacza wzrost ich liczby o $10,3 \% \mathrm{w}$ porównaniu z rokiem 2015 (54 778). Liczba stwierdzonych tego rodzaju przestępstw zwiększała się w latach 2009-2012, po czym w latach 2012-2015 doszło do spadku. W 2016 roku wśród 60,4 tys. stwierdzonych przez Policję przestępstw narkotykowych: $61,8 \%$ wszystkich przypadków dotyczyło posiadania narkotyków z art. 62 ustawy o przeciwdziałaniu narkomanii (w roku 2015: 60,2\%); 17,4\% - handlu narkotykami z art. 59 (w roku 2015: 17,9\%); natomiast 11,3\% - udzielania narkotyków z art. 58 (w roku 2015: 12,1\%).

\subsection{PODEJRZANI}

W 2016 roku zarzuty popełnienia przestępstw narkotykowych przedstawiono 29434 podejrzanym, co oznacza wzrost ich liczby o 9,4\% w porównaniu z rokiem 2015, w którym ustalono 26907 podejrzanych o przestępstwa narkotykowe. 


\subsection{NIELETNI SPRAWCY PRZESTĘPSTW NARKOTYKOWYCH}

W roku 2016 ustalono 2138 nieletnich sprawców przestępstw narkotykowych, czyli o 3\% mniej niż w roku 2015 (2204). W 2016 roku nieletni sprawcy przestępstw narkotykowych stanowili 7,3\% wszystkich ustalonych przez Policję sprawców przestępstw narkotykowych (w roku 2015 wskaźnik ten wynosił 8,2\%, w 2014: 9,8\%). Wśród ustalonych przez Policję w roku 2016 z 29,4 tys. sprawców przestępstw z ustawy o przeciwdziałaniu narkomanii: $82,7 \%$ stanowili podejrzani o posiadanie środków odurzających z art. 62 ustawy o przeciwdziałaniu narkomanii (w roku 2015: 80,4\%); 5,1\% o handel z art. 59 (5,4\%); 4\% o uprawę z art. 63 (4\%); 3,1\% o udzielanie innej osobie środków odurzających z art. 58 (3,7\%).

\section{BIBLIOGRAFIA}

BŁachut, J., Gaberle, A., Krajewski, K. (2004). Kryminologia. Gdańsk: Arche.

HoŁyst, B. (2016). Kryminologia. Warszawa: Wolters Kluwer.

JabŁoński, P., Bukowska, B., CzabaŁa, Cz. (red.) (2012). Uzależnienie od narkotyków. Podręcznik dla terapeutów. Warszawa: Krajowe Biuro do spraw Przeciwdziałania Narkomanii.

Jędrzejko, M. (2006). Patologie społeczne. Pułtusk: WSH im. A. Gieysztora.

J ĘDrzeJko, M. (2009). Narkomania. Spojrzenie wielowymiarowe. Pułtusk: WSH im. A. Gieysztora.

JęDRZEJKo, M. (2013). Narkotyki i środki zastępcze: zjawisko, zagrożenia, profilaktyka. Rozpoznawanie zachowań narkotykowych i dopalaczowych. Warszawa: Studio Poligraficzne Edytorka.

Nowak, A., Wysocka, E. (2001). Problemy i zagrożenia społeczne we współczesnym świecie. Elementy patologii społecznej i kryminologii. Katowice: Wydawnictwo Naukowe „Śląsk”.

PierzchaŁa, K. (2010). Narkomania jako wielowymiarowy problem społeczny. W: Z.E. Zieliński (red.), Rola informatyki w naukach ekonomicznych i społecznych. Innowacje i implikacje interdyscyplinarne (s. 222-229). Kielce: Wydawnictwo Wyższa Szkoła Handlowa.

PierzchaŁA, K. (2013). Kapelan więzienny w procesie resocjalizacji penitencjarnej. Toruń: Wydawnictwo Adam Marszałek.

PierzchaŁA, K. (2018). Forms of Rehabilitation's Effects Toward Dysfunctional Family [Formy oddziaływania resocjalizującego wobec dysfunkcjonalnej rodziny]. W: M. Przybysz-Zaremba, W. ZiareK (red.), FAMILY. Tasks - Help - Support. Selected Aspects (s. 249-263). Lithuania: Mykolas Romeris University in Vilnius. Academic Editing.

Pierzchala, K., Cekiera, Cz. (2008). Zwalczanie patologii spolecznych w systemie penitencjarnym Polski i USA. Toruń: Wydawnictwo Adam Marszałek.

Pierzchala, K., Cekiera, Cz. (2009). Człowiek a patologie społeczne. Toruń: Wydawnictwo Adam Marszałek.

Raport o stanie bezpieczeństwa w Polsce w 2016 roku (2017). Warszawa: Ministerstwo Spraw Wewnętrznych i Administracji. 
Soltysiak, T., KowalczyK-Jamnicka, M. (2007). Zjawiska patologiczne wśród młodzieży i możliwości przeciwdziałań. Bydgoszcz: Wydawnictwo UKW.

Struzik, M. (2007). Przestępstwa związane z narkotykami. Próba zdefiniowania zjawiska. Serwis informacyjny NARKOMANIA, 2(37), 5-8.

Ustawa o przeciwdziałaniu narkomanii 29 lipca 2005 r. Dz. U. 2005, nr 179, poz. 1485.

ZIĘBA, R. (2008). Bezpieczeństwo międzynarodowe po zimnej wojnie. Warszawa: Wydawnictwo Akademickie i Profesjonalne.

\section{NARKOMANIA JAKO CZYNNIK KRYMINOGENNY}

\section{Streszczenie}

Zjawisko zjawiska przestępczości narkotykowej staje się coraz bardziej powszechne w środowisku lokalnym. Jego zasięg, różnorodność i konsekwencje powodują, że należy je traktować jako poważnie zagrożenie. Skala prezentowanej patologii społecznej jest bardzo szeroka. Przestępczość powiązana ze środkami psychoaktywnymi jest coraz większym zagrożeniem dla społeczeństwa nie tylko ze strony narkomanii, lecz także związanego z tym zjawiskiem łamania prawnych i społecznych norm. Artykuł poświęcony jest problemowi narkomanii w Polsce, głównie przedstawia kryminogenny charakter narkomanii (przestępczość narkotykową). Porusza zagadnienie przestępczość zorganizowanej, czyli narkobiznesu, jak również ukazuje skalę i dynamikę opisywanego zjawiska.

Słowa kluczowe: narkomania; uzależnienie; kryminologia; przestępczość; przestępczość narkotykowa.

\section{DRUG ADDICTION AS A CRIMINOGENIC FACTOR}

\section{Summary}

The presence of drug-related crime is becoming more and more common in the local environment. Its range, diversity and consequences make them a serious threat. The scale of the presented social pathology is very wide. The association of crime and psychoactive substances is becoming an increasing threat to society not only from the side of drug addiction but also from the phenomenon of breaking legal and social norms. The article is devoted to the problem of drug addiction in Poland, mainly presenting the criminogenic nature of drug addiction (drug-related crime). He raises the problem of organized crime, or drug business, as well as shows the scale and dynamics of the phenomenon described.

Key words: drug addiction, addiction, criminology, criminality, drug crime. 